ORIGINAL ARTICLE

\title{
Do e-athletes move? A study on physical activity level and body composition in elite e-sports
}

\author{
Akan Bayrakdar ${ }^{1 \mathrm{ABCDE}}$, Yağmur Yıldız ${ }^{2 \mathrm{ABCDE}}$, Işık Bayraktar ${ }^{3 \mathrm{ABCDE}}$ \\ ${ }^{1}$ Bingöl University, Turkey \\ ${ }^{2}$ Aksaray University, Turkey \\ ${ }^{3}$ Alanya Alaaddin Keykubat University, Turkey
}

Authors' Contribution: A - Study design; B - Data collection; C - Statistical analysis; D - Manuscript Preparation; E - Funds Collection.

\begin{abstract}
Purpose:

Material:

The aim of this study is to determine the effect of e-sports on physical activity level and body composition. The athletes who participated in the study were $19.92 \pm 2.21$ years of age, $1.73 \pm 0.04 \mathrm{~m}$ body height and $78.35 \pm 6.52 \mathrm{~kg}$ body weight. A total of 137 athletes participated in the study, including 27 from Turkey, 47 from South Korea and 63 from the United States (USA). The data was collected by e-mail from the sports clubs. The athletes who representing their country in international competitions involved in the study. The data obtained were evaluated in the SPSS program.

Results: $\quad$ According to the findings of the study, the body mass index (BMI) of e-sport athletes is $26.03 \pm 1.85$, the number of physical activity steps is $6646 \pm 3400$ and the daily e-sport hours are $9.34 \pm 1.12$. The BMI was determined as USA 26.12, South Korea 26.02 and Turkey 25.84 respectively. The number of physical activity steps was identified as 5255 steps in the US, 7785 steps in South Korea and 7909 steps in Turkey. The daily e-sports hour is set at US 9.63 hours, Turkey 9.29 hours and South Korea 8.97 hours. In comparison of country-based athletes, there was a significant difference between physical activity level and daily e-sports hours at $p<0.05$. The value of $\mathrm{BMI}$ is not different. Although it is not statistically related to the physical activity level and BMI. There was no statistically significant relationship between daily e-sports hours and BMI and physical activity step counts. However, as the time of e-sports increases, BMI increases and the number of physical activity steps decreases.

Conclusions: As a result it is seen in the findings of the research that athletes dealing with e-sports are included in the fat group as a body composition and their daily physical activity steps are low. In addition, according to the results of the research, e-sports are thought to have negative effects on physical health. Thanks to the physical activity programs to be applied to these athletes, it is thought that their body composition and physical activity levels can be improved.

Keywords: e-sports, physical activity, body composition.
\end{abstract}

\section{Introduction}

In recent years, a new concept called e-sports has entered our lives. e-Sports is defined as a sport where people from all over the world can meet and play via the internet, or people from different parts of the world can meet and play through international big electronic sports organizations organized at certain times. Most people are not yet aware of the concept of e-sports. But e-sports events also have star players, fan base, teams, jerseys and leagues. Only all events take place online or on local networks [1].

Today, many national and international e-sports tournaments are held. These tournaments have made a great contribution to the development and expansion of electronic sports and athlete concepts by providing players with a professional environment in which to compete. The number of official and private tournaments held every day and the interest shown to these tournaments is increasing, and accordingly, e-athletes are allowed to perform this as a professional profession. Nowadays, e-sports tournaments have become big events, with prizes of up to millions of dollars and thousands of viewers watching (c) Akan Bayrakdar, Yağmur Yıldız, Işık Bayraktar, 2020 doi:10.15561/20755279.2020.050 live broadcasts in arenas and hundreds of thousands on the internet. Hundreds of e-sports clubs have been established that operate in different areas of e-sport and are gathered under the umbrella of various companies and sponsors, and these clubs train regularly, compete in various leagues and tournaments, and strengthen their staff by making transfers when necessary. In addition, e-athletes in various countries of the world are now counted as athletes and have started to receive athlete licenses. A research in recent years has shown that e-sports has increased as well as its audience [2]. With each passing year, the e-sports economy is growing rapidly [3], and experts say that it will grow even bigger, especially with the covid-19 outbreak occurring in 2020.

Despite all this popularity, e-sports has some negative physical and spiritual aspects, because the players mostly do not even act [4]. Also, e-sports tournament awards have reached surprising amounts in recent years. For this reason, e-athletes started to spend more time at the computer [5]. Thus, unhealthy changes such as physical inactivity and increase in body composition occur in these athletes. The main difference between e-sports and traditional sports is physical mobility. The most alarming 
thing about e-sport is that players sit at a computer for hours. Rudof, who has been studying e-sport performance and health at the Cologne sports academy for 8 years, states that amateur or professional e-athletes play an average of 24-25 hours a week [6]. In addition, during the tournament players stated that they stayed in the seat for more than 12 hours daily [7].

The aim of this study is to determine the effect of e-sports on physical activity level and body composition.

This section contains information from studies on how e-sport affects players and what the potential health effects are. Selected studies highlight the negative effects of e-sport on health from different perspectives.

It is stated that e-sports players are not physically active due to sedentary time for a long time. In some studies, it is claimed that long-term sedentary life will result in obesity, cardiovascular disorders, chronic diseases, mental illnesses, weakening in motor skills and low cognitive development [8,9]. DiFrancisco-Donoghue et al. [10] reported that players complain more about physical health, eye strain, neck and back pain rather than wrist and hand pain. In addition, while talking about the effects of e-sports on health $[11,12]$, potential "addiction" and "psychological disorders" should not be ignored [13, 14]. As a different approach; such addictive e-sports games can be compared to gambling, alcohol or smoking. With esports games, gambling addiction increases and it is stated that esports players experience stress during competition activities $[15,16]$.

Research shows that sitting 6 hours a day for two weeks in a row can increase bad cholesterol levels. When the muscles begin to degenerate $[17,18]$, they prevent blood flow to the heart $[19,20]$ and increase the risk of weight gain $[21,22]$ and heart disease $[23,24)$. Rudolf et al [25] even states that the exercise performed after the sedentary period does not compensate for the damage caused by excessive sitting. In addition, the study is stated that these observations are confirmed and "players must move between the games and leave the screen for a while".

Purpose. The aim of this study is to determine the effect of e-sports on physical activity level and body composition.

\section{Material and methods}

\section{Participants}

The athletes who participated in the study had an average body length of $19.92 \pm 2.21$ years old, a height of $1.73 \pm 0.04 \mathrm{~m}$ and a body weight of $78.35 \pm 6.52 \mathrm{~kg}$. A total of 137 male athletes participated in the study, including 27 from Turkey, 47 from South Korea and 63 from the United States (USA). The data was collected by e-mail from the sports clubs. The athletes who representing their country in international competitions involved in the study. In addition, having been licensed in e-sports and representing the country in international competitions has been determined as the criteria for participation in the research.
Determination of sample size

$\mathrm{G}$ *Power 3.1.9.4 software was used to determine the number of samples in the study. Power analysis was conducted in the light of available data from similar studies in the literature. In the power analysis, the Alpha meaning level (Type I error) was taken as $\alpha=0.05$ and the Power Value (Type II error) was taken as $\beta=0.95$. In order for the validity of our study to be high, the width of the effect was taken as $|\rho|=0.1$. As a result of these, the number of people to be included in the study was determined to be at least 64 .

\section{Collection of Data}

Age, body height, body weight, number of physical activity steps and daily e-sport activity times are taken from the clubs to which the athletes are licensed. e-Sports clubs in Turkey, South Korea and USA were informed about the purpose of the research and requested data on the above mentioned characteristics of the athletes. In total, 21 different clubs have been e-mailed and 17 of them have been repatriated.

Body composition: BMI calculation was calculated using the formula body weight / height ${ }^{2}$. According to BMI classification, over $25 \%$ are stated as fat and over $30 \%$ as obese [26].

Physical activity level: Tudor-Locke and Bassett introduced the concept of graduated step index for healthy adults: 1 ) $<5000$ steps/day ('inactive');

2) 5.000-7.499 steps/day (low-active');

3) 7.500-9.999 steps/Day (a little'active');

4) $\geq 10.000-12.499$ steps/Day ('active');

5) $\geq 12.500$ steps/day ('very active') [27].

Statistical Analysis.

The data obtained were evaluated in the SPSS 23 package program. Arithmetic mean and standard deviation values of age, length of height and body weight were calculated according to countries. One-way variance analysis of BMI, physical activity level and daily e-sports hours by country was compared with Anova. Tukey HSD test $[28,29]$ was used to determine the difference in case of Anova result. In addition, correlation analysis was applied to determine the relationship between variables.

\section{Results}

The participants in the study were $19.92 \pm 2.21$ years of age, $1.73 \pm 0.04 \mathrm{~m}$ height length and $78.35 \pm 6.52 \mathrm{~kg}$ body weight (shown in Table 1).

The BMI value of e-sport athletes is $26.03 \pm 1.85 \mathrm{~kg} /$ $\mathrm{m}^{2}$, the number of physical activity steps is $6646 \pm 3400$ steps and the daily e-sport hours are $9.34 \pm 1.12$ hours. Body mass index value was determined as USA 26.12 $\mathrm{kg} / \mathrm{m}^{2}$, South Korea $26.02 \mathrm{~kg} / \mathrm{m}^{2}$ and Turkey $25.84 \mathrm{~kg} / \mathrm{m}^{2}$ respectively. The number of physical activity steps was determined as 5255 steps for USA, 7785 steps for South Korea and 7909 steps for Turkey. Daily e-Sports time was determined as 9.63 hours for USA, 9.29 hours for Turkey and 8.97 hours for South Korea. In comparison of country-based athletes, there was a significant difference between physical activity level and daily e-sports hours at $\mathrm{p}<0.05$. There was no difference in BMI values (Table 2 ). 
Table 1. Average age, height and body weight values of participants by country

\begin{tabular}{llll}
\hline Variables & Countries & $\mathbf{N}$ & $\overline{\mathbf{x}} \pm$ SD \\
\hline \multirow{3}{*}{ Age (years) } & Turkey & 27 & $20.14 \pm 2.29$ \\
& South Korea & 47 & $19.14 \pm 2.18$ \\
& USA & 63 & $20.41 \pm 2.06$ \\
& Total & 137 & $19.92 \pm 2.21$ \\
\hline \multirow{3}{*}{ Length $(\mathbf{m})$} & Turkey & 27 & $1.71 \pm .03$ \\
& South Korea & 47 & $1.70 \pm .03$ \\
& USA & 63 & $1.76 \pm .04$ \\
Body weight $(\mathbf{k g})$ & Total & 137 & $1.73 \pm .04$ \\
& Turkey & 27 & $75.85 \pm 6.24$ \\
& South Korea & 47 & $75.91 \pm 5.23$ \\
& USA & 63 & $81.23 \pm 6.40$ \\
\hline
\end{tabular}

Table 2. Comparison of participants' BMI, physical activity level and daily e-sports hours by country

\begin{tabular}{|c|c|c|c|c|c|c|}
\hline Variables & Countries & $\mathbf{N}$ & $\overline{\mathbf{x}} \pm \mathrm{SD}$ & $\mathbf{F}$ & $\mathbf{p}$ & Tukey HSD \\
\hline \multirow{4}{*}{$\begin{array}{l}\text { Body Mass Index } \\
(\mathrm{BMI}) \mathrm{kg} / \mathrm{m}^{2}\end{array}$} & Turkey & 27 & $25.84 \pm 2.23$ & \multirow{4}{*}{.213} & \multirow{4}{*}{.808} & \multirow{4}{*}{---} \\
\hline & South Korea & 47 & $26.02 \pm 1.94$ & & & \\
\hline & USA & 63 & $26.12 \pm 1.60$ & & & \\
\hline & Total & 137 & $26.03 \pm 1.85$ & & & \\
\hline \multirow{4}{*}{$\begin{array}{l}\text { Physical Activity } \\
\text { Level } \\
\text { (step) }\end{array}$} & Turkey & 27 & $7909 \pm 2982$ & \multirow{4}{*}{$11.238 *$} & \multirow{4}{*}{.000} & \multirow{4}{*}{$\begin{array}{l}\text { USA- Turkey* } \\
\text { USA- South Korea* }\end{array}$} \\
\hline & South Korea & 47 & $7785 \pm 3018$ & & & \\
\hline & USA & 63 & $5255 \pm 3350$ & & & \\
\hline & Total & 137 & $6646 \pm 3400$ & & & \\
\hline \multirow{4}{*}{$\begin{array}{l}\text { Daily e-Sports } \\
\text { (hour) }\end{array}$} & Turkey & 27 & $9.29 \pm .82$ & \multirow{4}{*}{$4.848^{*}$} & \multirow{4}{*}{.009} & \multirow{4}{*}{ USA- South Korea* } \\
\hline & South Korea & 47 & $8.97 \pm 1.09$ & & & \\
\hline & USA & 63 & $9.63 \pm 1.19$ & & & \\
\hline & Total & 137 & $9.34 \pm 1.12$ & & & \\
\hline
\end{tabular}

Table 3. Correlation results between participants' research variables

\begin{tabular}{llll}
\hline Variables & Body weight $\mathbf{( k g )}$ & $\begin{array}{l}\text { BMI } \\
\left(\mathbf{k g} / \mathbf{m}^{\mathbf{2}}\right)\end{array}$ & $\begin{array}{l}\text { Physical Activity Level } \\
\text { (Step) }\end{array}$ \\
\hline Body mass index (BMI) $\mathbf{k g} / \mathbf{m}^{\mathbf{2}}$ & $.735^{* *}$ & & \\
Physical Activity Level (Step) & -.080 & -.013 & -.156 \\
Daily e-Sports (hours) & .074 & .033 & -.036 \\
\hline
\end{tabular}

$* \mathrm{p}<0.05$

Although there is no statistically significant relationship between physical activity level and BMI, it is seen in the table that this relationship is negative. There was no statistically significant relationship between daily e-sports hours and BMI and physical activity step numbers. However, as the time of e-sports increases, BMI increases and the number of physical activity steps decreases (Table 3 ).

\section{Discussion}

Long-term sedentary behavior is considered a risk factor for many chronic diseases $[30,31]$ and mortality due to these diseases $[32,33]$. Because of the nature of e-sports, time is spent in front of the screen for a long time, and the risks of disease due to physical inactivity increase
$[6,34]$. e-Sports are reported to have health advantages and disadvantages [35]. However, the main disadvantage is physical inactivity and the risk of obesity. Our study is important because it aims to reveal these disadvantages.

In addition, with the rise of the e-game industry, the concept of "professional game career" emerged. Professional e-sports players have the same athlete status as people in other sports. The gaming industry is now a sports event and the rewards reaching million dollars have made the professional gaming career even more attractive. The interest in traditional sports has decreased and interest in e-sports has increased. Today, some of the young people are thinking about earning their lives by playing games or publishing their games. Since e-sports is a type of sports sitting by the screen, sedentary life time 
has started to increase. With the sedentary life, people started not moving and gaining weight.

Daily e-sports playing or training times vary in the literature. In our study, daily e-sports duration was determined as $9.34 \pm 1.12$ hours. The daily e-sports duration is approximately 5-6 hours. The time difference between our study and the literature is thought to be due to players doing e-sport professionally or recreationally. Mustafaoglu et al. [36] found that e-athletes had weekly offline training time of $17,10 \pm 15.40$ hours, weekly online training time of $25.10 \pm 23.80$ hours and weekly total training time of $42.09 \pm 34.8$ hours. It was found that around six hours of e-sports were performed when it was calculated on a daily basis. In their study with elite e-athletes, Kari \& Karhulahti [37] stated that the daily e-sports duration was 5.28 hours. Rudolf et al [6] set the players ' daily e-sports time at 7.7 hours.

BMI's of e-athletes subject to our study were determined to be $26.03 \pm 1.85 \mathrm{~kg} / \mathrm{m}^{2}$. This finding is indicated as obesity according to BMI assessment criteria [26]. In their study on e-sports players, Rudolf et al [6] found BMI to be in the $24.6 \pm 4.8 \mathrm{~kg} / \mathrm{m}^{2}$ and fat group. Mustafaoglu et al. [36] determined the BMI of e-sports players to be $24.3 \pm 5.1 \mathrm{~kg} / \mathrm{m}^{2}$. It is stated that body fat tissue increases with the increase of sedentary time $[9,16]$ and this time will cause obesity formation with more than 8 hours, thus many diseases will occur [38].

Physical inactivation and sedentary behaviors were reported in athletes in association with e-sports $[8,10]$, while some studies have reported that these athletes are physically active and healthy $[39,40]$. In our study,

\section{References}

1. Kocadağ M. Electronic sports career and training. Journal of Trends in Eastern Anatolia Social Sciences, 2007; 1(2): 49-63.

2. Dorsey P. 'League of Legends' ratings top NBA finals. World Series clinchers; 2014.

3. Global Games Market Will Grow $9.4 \%$ to $\$ 91.5 B n$ in 2015. [Internet]. 2015. [updated 2015; cited 2019 Nov 23]. Available from: https://newzoo.com/insights/ articles/global-games-market-will-grow-9-4-to91-5bn-in-2015/\#: : text=Amsterdam\%2FSan\%20 Francisco $\% 2$ FShanghai $\% 2$ C, reach $\% 20 \% 24107 \mathrm{Bn} \% 20$ in $\% 202017$

4. Jenny SE, Manning RD, Keiper MC, Olrich TW. Virtual(ly) Athletes: Where eSports Fit Within the Definition of "Sport." Quest ,2017;69:1-18. https://doi.org/10.1080/00336297.2016.1144517

5. Dota 2. The International Dota 2 Champoinships 2016. [Internet]. 2016. [updated 2016; cited 2019 Nov 23]. Available from: https:/game-tournaments.com/dota-2/ international-2016

6. Rudolf K, Bickmann P, Froböse I, Tholl C, Wechsler K, Grieben C. Demographics and Health Behavior of Video Game and eSports Players in Germany: The eSports Study 2019. International Journal of Environmental Research and Public Health, 2020;17:1870. https://doi.org/10.3390/ijerph17061870

7. Rayat P. E-sports into the sports movement?: Sports associations and their perceptions of and approaches to future e-sports in their own business. [Thesis]. Faculty of physical activity levels of e-sports players were found to be physically poor with $6646 \pm 3400$ steps according to Tudor-Locke \& Bassett [41] physical activity level Determination criteria. Despite not included in the subject of our study, many studies have reported that physically sedentary e-athletes feel pain in different parts of their bodies [10]. Furthermore, Kari \& Karhulahti [37] stated that more than half $(55.6 \%)$ of elite e-athletes believe that e-sport performance will improve by integrating physical activity into the exercise program.

\section{Conclusion}

As a result, BMI increases as the level of physical activity decreases, BMI increases as the daily e-sport hours increase, and the level of physical activity decreases. It is thought that physical activity or training programs to be implemented with e-sports will increase the level of physical activity, and thanks to this, BMI will remain within the normal limits.

\section{Acknowledgements}

This study was written by abridging Akan Bayrakdar, Yağmur Yıldız and Işık Bayraktar. No grants or financial aids were taken in this Project.

\section{Financial support}

There is no financial support.

\section{Conflict of interest}

The authors declare no conflict of interest.

Social Sciences, Department of Education. Umeå University; 2017.

8. Choi C, Hums M, Bum C-H. Impact of the Family Environment on Juvenile Mental Health: eSports Online Game Addiction and Delinquency. International Journal of Environmental Research and Public Health, 2018;15:2850. https://doi.org/10.3390/ijerph15122850

9. Cunningham GB, Fairley S, Ferkins L, Kerwin S, LockD, Shaw S, et al. eSport: Construct specifications and implications for sport management. Sport Management Review, 2018;21:1-6. https://doi.org/10.1016/j.smr.2017.11.002

10.DiFrancisco-Donoghue J, Balentine J, Schmidt G, Zwibel H. Managing the health of the eSport athlete: an integrated health management model. BMJ Open Sport Exerc Med, 2019;5:e000467. https://doi.org/10.1136/bmjsem-2018-000467

11. Griffiths MD. Computer game playing and social skills: a pilot study. Aloma: Revista de Psicologia, Ciències de l'Educació i de l'Esport, 2010;27: 301-310.

12.Khoo A. E-social Networking and eSports. In: More or Less Democracy \& New. 2012. P. 258-273.

13. Griffiths MD. The psychosocial impact of professional gambling, professional video gaming \& eSports. Casino \& Gaming International, 2017; 28; 59-63.

14.Nielsen RKL, Karhulahti V-M. The problematic coexistence of "internet gaming disorder" and esports. Proceedings of the International Conference on the Foundations of Digital Games - FDG '17, Hyannis. Massachusetts: ACM Press; 2017. P. 1-4. https://doi.org/10.1145/3102071.3106359 
15.HallmannK, GielT.eSports-Competitivesportsorrecreational activity? Sport Management Review, 2018;21:14-20. https://doi.org/10.1016/j.smr.2017.07.011

16.Polman R, Trotter M, Poulus D, Borkoles E. eSport: Friend or Foe? In: Göbel S, Garcia-AgundezA, Tregel T, Ma M, Baalsrud Hauge J, Oliveira M, et al., editors. Serious Games, vol. 11243, Cham: Springer International Publishing; 2018. P. 3-8. https://doi.org/10.1007/978-3-030-02762-9_1

17.Ilhan $\mathrm{L}$. The culture of sedentary lives and the accompanying. Journal of Productivity, 2010; (3): 195-210.

18.Crawford D, Jeffery R, French S. Television viewing, physical inactivity and obesity. Int J Obes, 1999;23:437-40. https://doi.org/10.1038/sj.ijo.0800845

19.Bulut S. A social determinants of health, physical activity. Turk Hij Den Biyol Derg, 2013;70:205-14. https://doi.org/10.5505/TurkHijyen.2013.67442

20.Çakır B. Healthy Living: Can We Reduce The Health Risks We Encounter In Everyday Life ?. Ankara Medical Journal, 2017; 17(3): 179-188.

21.Katzmarzyk PT, Janssen I. The Economic Costs Associated With Physical Inactivity and Obesity in Canada: An Update. Can J Appl Physiol, 2004;29:90-115. https://doi.org/10.1139/h04-008

22.Blair SN, Brodney S. Effects of physical inactivity and obesity on morbidity and mortality: current evidence and research issues.Medicine \&ScienceinSports \& Exercise, 1999;31:S646. https://doi.org/10.1097/00005768-199911001-00025

23.Cecchini M, Sassi F, Lauer JA, Lee YY, GuajardoBarron V, Chisholm D. Tackling of unhealthy diets, physical inactivity, and obesity: health effects and cost-effectiveness. The Lancet, 2010;376:1775-84. https://doi.org/10.1016/S0140-6736(10)61514-0

24.ten Hacken NHT. Physical Inactivity and Obesity: Relation to Asthma and Chronic Obstructive Pulmonary Disease? Proceedings of the American Thoracic Society, 2009;6:663-7. https://doi.org/10.1513/pats.200907-070DP

25.Rudolf K, Grieben C, Achtzehn S, Froböse I. Stress im eSport-Ein Einblick in Training und Wettkampf. In: eSport conference Professionalisierung einer Subkultur. 2010. P. $100-105$.

26. Centers for Disease Control (CDC). Growth Charts for the United States: Methods and Development. [Internet]. 2020. [updated 2019; cited 2019 Nov 02]. Available from: http:// www.cdc.gov/nchs/data/series/sr_11/sr11_246.pdf

27.Tudor-Locke C, Craig CL, Brown WJ, Clemes SA, De Cocker K, Giles-Corti B, et al. How many steps/day are enough? for adults. Int J Behav Nutr Phys Act, 2011;8:79. https://doi.org/10.1186/1479-5868-8-79

28.Exploratory Data Analysis. The Concise Encyclopedia of Statistic. New York, NY: Springer New York; 2008. P. 192-4. https://doi.org/10.1007/978-0-387-32833-1_136

29.Haynes W. Tukey's Test. In: Dubitzky W, Wolkenhauer O, Cho K-H, Yokota H, editors. Encyclopedia of Systems Biology, New York, NY: Springer New York; 2013. P. 2303-4. https://doi.org/10.1007/978-1-4419-9863-7_1212
30.Bailey DP, Hewson DJ, Champion RB, Sayegh SM. Sitting Time and Risk of Cardiovascular Disease and Diabetes: A Systematic Review and Meta-Analysis. American Journal of Preventive Medicine, 2019;57:408-16. https://doi.org/10.1016/j.amepre.2019.04.015

31.Biswas A, Oh PI, Faulkner GE, Bajaj RR, Silver MA, Mitchell MS, et al. Sedentary Time and Its Association With Risk for Disease Incidence, Mortality, and Hospitalization in Adults: A Systematic Review and Meta-analysis. Ann Intern Med, 2015;162:123. https://doi.org/10.7326/M14-1651

32. Chau JY, Grunseit AC, Chey T, Stamatakis E, Brown WJ, Matthews CE, et al. Daily Sitting Time and All-Cause Mortality: A Meta-Analysis. PLoS ONE, 2013;8:e80000. https://doi.org/10.1371/journal.pone.0080000

33.RezendeLFM, SáTH,MielkeGI,ViscondiJYK, Rey-LópezJP, Garcia LMT. All-Cause Mortality Attributable to Sitting Time. American Journal of Preventive Medicine, 2016;51:253-63. https://doi.org/10.1016/j.amepre.2016.01.022

34.Patterson R, McNamara E, Tainio M, de Sá TH, Smith $\mathrm{AD}$, Sharp SJ, et al. Sedentary behaviour and risk of allcause, cardiovascular and cancer mortality, and incident type 2 diabetes: a systematic review and dose response meta-analysis. Eur $J$ Epidemiol 2018;33:811-29. https://doi.org/10.1007/s10654-018-0380-1

35.Happonen A, Minashkina D. Professionalism in Esports: benefits in skills and health and possible downsides. Lappeenranta; 2019.

36.Mustafaoğlu R, Zirek E, Yasacı Z. Demographic Features, Playing Times and Successes of e-Sports Players. Journal of Addiction, 2018; 19(4): 115-122.

37.Kari T, Karhulahti V-M. Do E-Athletes Move?: A Study on Training and Physical Exercise in Elite E-Sports. International Journal of Gaming and Computer-Mediated Simulations, 2016;8:53-66. https://doi.org/10.4018/IJGCMS.2016100104

38.Funk DC, Pizzo AD, Baker BJ. eSport management: Embracing eSport education and research opportunities. Sport Management Review, 2018;21:7-13. https://doi.org/10.1016/j.smr.2017.07.008

39.Funk DC, Pizzo AD, Baker BJ. eSport management: Embracing eSport education and research opportunities. Sport Management Review, 2018;21:7-13. https://doi.org/10.1016/j.smr.2017.07.008

40.Dubbels BR. Exploring the Cognitive, Social, Cultural, and Psychological Aspects of Gaming and Simulations. IGI Global; 2019. https://doi.org/10.4018/978-1-5225-7461-3

41.Tudor-Locke C, Bassett DR. How Many Steps/ Day Are Enough?: Preliminary Pedometer Indices for Public Health. Sports Medicine, 2004;34:1-8. https://doi.org/10.2165/00007256-200434010-00001 


\section{Information about the authors:}

Akan Bayrakdar; (Corresponding author); https://orcid.org/0000-0002-3217-0253; akanbayrakdar@gmail.com; School of Physical Education and Sport, Bingöl University; Bingöl, Turkey.

Yağmur Yıldız; https://orcid.org/0000-0001-6852-2364; yagmurryildiz@hotmail.com; Specialization Coordinator in Sports and Health, Aksaray University; Aksaray, Turkey.

Işık Bayraktar; https://orcid.org/0000-0003-1001-5348; drisikb@icloud.com; Faculty of Sport Sciences, Alanya Alaaddin Keykubat University; Alanya, Turkey.

Cite this article as:

Bayrakdar A, Yıldız Y, Bayraktar I. Do e-athletes move? A study on physical activity level and body composition in elite e-sports. Physical Education of Students, 2020;24(5):259-264.

https://doi.org/10.15561/20755279.2020.0501

This is an Open Access article distributed under the terms of the Creative Commons Attribution License, which permits unrestricted use, distribution, and reproduction in any medium, provided the original work is properly cited http://creativecommons.org/licenses/by/4.0/deed.en

Received: 17.06.2020

Accepted: 12.08.2020; Published: 30.10 .2020 